\title{
Young people's uses of celebrity: class, gender and 'improper' celebrity
}

Kim Allen, Institute for Policy Studies in Education, London Metropolitan University Heather Mendick (School of Sport \& Education, Brunel University)

\section{(Received ; final version )}

\begin{abstract}
In this paper, we explore the question of how celebrity operates in young people's everyday lives, thus contributing to the urgent need to address celebrity's social function. Drawing on data from three studies in England on young people's perspectives on their educational and work futures, we show how celebrity operates as a classed and gendered discursive device within young people's identity work. We illustrate how young people draw upon class and gender distinctions that circulate within celebrity discourses (proper/improper, deserving/undeserving, talented/talentless, respectable/tacky) as they construct their own identities in relation to notions of work, aspiration and achievement. We argue that these distinctions operate as part of neoliberal demands to produce oneself as a 'subject of value'. However, some participants produced readings that show ambivalence and even resistance to these dominant discourses. Young people's responses to celebrity are shown to relate to their own class and gender position.
\end{abstract}

Keywords: celebrity; gender; class; aspirations; neoliberalism

\section{Introduction}

In England, as in many Western countries, celebrity is increasingly important. Media and policy discussions of young people and celebrity in England contain contradictory messages. Celebrities have been used as 'role models' promoting educational initiatives, from footballers endorsing literacy (National Literacy Trust, 2007/8) to their 'Wives And Girlfriends' (WAGs, see later) praised and paraded for having Alevels, which are the 'gold standard' post-compulsory educational qualifications (Learning and Skills Council, 2007). Alongside this, there are growing concerns that young people value fame in and of itself, rather than seeking achievement through hard work or skill. These concerns have been raised by many organisations and individuals, including UK teachers' unions (BBC, 2008; Woolcock, 2008) and the UK culture minister (Chapman, 2008). They are situated within wider political concerns in the UK around young people's relationship with the commercial world 
and 'sexualised' culture, marked by a raft of government commissioned reviews (DCSF/DCMS, 2009; Papadopoulos, 2010)

We want to interrupt dominant public discourses which either trivialise young people's celebrity consumption or judge it harmful. Both responses ignore the contemporary significance of celebrity; they assume an obviousness to young people's relationship to celebrity and thus homogenise young people. We draw on three interconnected studies examining young people's perceptions of work and their educational and career 'aspirations' ${ }^{1}$. In this way we are contributing to the urgent need to address the social function of celebrity (Turner, 2010). We argue that celebrity operates as a discursive device which structures young people's relationships to education and work within neoliberalism. Attending to young people's active negotiation of their cultural worlds, we examine how their uses of celebrity can both reproduce and, importantly, resist dominant classed and gendered discourses of selfhood: discourses which make moral distinctions between celebrities and construct fame as an inappropriate ambition. Before turning to these young people's accounts we introduce our conceptualisation of celebrity and set out its relationship to neoliberal regimes of selfhood.

\section{Celebrity discourses: neoliberalism, social class and gender}

In this paper we illustrate how celebrity operates within a range of discursive practices (including the family, school and wider popular culture) through which young people are positioned and position themselves (Willett, 2011 in press). These practices are infused by relations of power and practices of exclusion. Through them distinctions are made and certain relations, behaviours and people are given or denied value. We understand celebrity as defined through discourses: historically and culturally specific configurations of meanings that make certain ways of thinking and 
being possible and others impossible (Foucault, 1972). Using this approach we can explore how celebrity consumption is informed by the current neoliberal regime which is oriented around the rational, enterprising and self-regulating individual who is responsible for their life choices and trajectories (du Gay, 1996; Rose, 1999). In this section we look at existing research on celebrity culture and the regulation of classed and gendered selves within neoliberalism. We identify dominant discourses of class and gender within celebrity culture before turning our attention to how our studies' participants negotiated these discourses in their 'identity work'.

Celebrity discourses have been shown to enact wider practices of social distinction in which the working-class are positioned as Other. Tyler and Bennett (2010, p. 376) argue that dominant discourses within celebrity culture establish 'social hierarchies and processes of social abjection'. They illustrate that while some celebrities hold high public esteem, others - namely the 'celebrity chav' (workingclass or 'white trash' female celebrities such as ex-pop singer Kerry Katona and Big Brother contestant Jade Goody ${ }^{2}$ - are constituted as illegitimate, undesirable and lacking. Similar claims are made by Skeggs and Wood (2008) in a rare empirical study which touches on celebrity. Examining women's engagement with Reality TV, Skeggs and Wood argue that Reality TV promotes a neoliberal 'subject of value' based on middle-class selfhood: working-class participants are found wanting, lacking the right culture and tastes and thus requiring correction and transformation. As such, Reality TV literally makes class by constituting certain selves as proper and others as improper and by inciting audiences to make moral judgements about selfhood.

Working-class celebrities are represented through their excessive and troublesome bodies and lifestyles. Yet, the classification of these abject others is not 
just a judgement of their body or lifestyle. It is also a judgement of their 'lack' of economic value:

One of the main processes by which the "subject of value" can be distinguished from its constitutive limit is via the amount of labour that is made evident in its making. As a moral imperative people have to show that they are working on their own development, establishing value in their own subjectivity, extending their cultural exchange value. (Skeggs, Wood, \& Thumim, 2007)

The 'celebrity chav' or Reality TV star is thus positioned as lacking moral and economic value: their fame is constructed as accidental, improper, achieved not through labour (hard work, education, training or the application of talent and ability) but through luck, manipulation or proximity to other celebrities. They represent the undeserving and the undesirable. Indeed, the 'celebrity chav' and Reality TV star are associated with the proliferation of 'easy' pathways to fame which are said to characterise modern celebrity. Along with glamour models and WAGs (Wives and Girlfriends of footballers, see below) they are seen to be unable to display evidence of acceptable labour by which to legitimise their status and worth, thereby playing a central role in the demarcation of proper and improper selfhood and fame.

It is not just class that underlines judgements of proper and improper fame but also gender: it is the female working-class celebrity in particular that is constructed as abject other. Negra and Holmes (2008) have observed how female celebrities specifically have been mobilized within debates about the current 'crisis' of celebrity, to represent a perceived evacuation of talent and hard work from contemporary fame. WAGs, glamour models and (mostly female) Reality TV stars have come to epitomise the talentless, undeserving, and hence valueless celebrity in the UK. These celebrities are typically positioned as acquiring success through the use of their bodies rather than their minds: as sexualised glamour models, conspicuous consumers or through publicising their bodily transformation (through diets, fitness regimes or cosmetic surgery). The WAG is an exemplar. This acronym has emerged as a visible and 
prolific cultural reference which wikipedia captures as: 'used particularly (but not exclusively) by the British tabloid press to describe the Wives And Girlfriends of high-profile footballers, originally the England national football team' (http://en.wikipedia.org/wiki/WAGs). Thus, by definition, WAGs' celebrity status is defined by their role as significant other to a talented, and so legitimately famous, male footballer. This form of celebrity femininity is often read as a failure of ambition. In this latter construction, women are seen as using their sexuality to get ahead and as 'free-loaders' desiring conspicuous consumption using their partner's, not their own, money (paralleling the manipulative sexuality of the femme fatale (Tasker, 1998)).

Thus particular constructions of contemporary femininity are derided and scorned for failing to enact idealised femininity. They are marked as Other to the sexually and socially independent, 'have it all girl' of neoliberalism (McRobbie, 2004, 2008; Walkerdine, Lucey, \& Melody, 2001). Indeed analysis of media texts has illuminated how celebrity culture powerfully articulates new ideals of neoliberal femininity, oriented around self-responsibility, compulsory success in education and work and self-reinvention (Allen, 2009; Ringrose \& Walkerdine, 2008). Class and gender are thus integral to the ways in which the neoliberal subject is constructed through celebrity.

The overwhelming majority of scholarship on celebrity has examined representations of celebrities through textual analysis (Turner, 2010). This has provided important insights, for example, into the centrality of discourses of meritocracy, talent, success and failure to the discursive terrain of celebrity culture (Couldry, 2000; Dyer, 2003; Littler, 2004). However, being text-based, such analysis does not attend to how people use celebrity, taking-up, negotiating and resisting the 
dominant discourses that circulate within it. Furthermore, a lack of attention to young people's voices risks reifying the obviousness assumed in wider public debates. We argue that a turn to the empirical is vital if we are to understand the complexity of celebrity's social function. Indeed as Ang (1996) argues:

\footnotetext{
fieldwork among audiences - in the broad sense of engaging oneself with the unruly and heterogeneous practices and accounts of real historical viewers or readers - helps to keep our critical discourses from becoming closed texts of Truth, because it forces the researcher to come to terms with perspectives that may not be easily integrated in a smooth, finished and coherent Theory. (Ang, 1996, pp. 514-515)
}

There is empirical work that illuminates the role of popular and commercial media as an inextricable and embedded aspect of young people's everyday lives (Buckingham \& Bragg, 2004; Marsh et al., 2005). While valuable, this has not attended to the practices of exclusion that are taken up in young people's engagement with celebrity: that is how discourses within celebrity enact and inscribe particular classed and gendered identities. Some work on girls' engagement with popular culture points to how it operates as a site in which the contemporary neoliberal project of femininity is articulated, regulating girls' performances of a classed and raced ‘idealised’ femininity (Nayak \& Kehily, 2008; Read, 2011; Willett, 2011 in press). But equally, it is not specifically concerned with celebrity culture.

In this paper we show that focussing on the consumption of celebrity culture that is on young people's uses of celebrity - and foregrounding young people's voices can open up new perspectives on how distinctions that circulate within celebrity culture play out in young people's identity work. 'Identity work' is understood here as the ongoing processes through which people come to understand 'who I am' and their place in the world. The idea that identity requires work draws on poststructuralist approaches to the self. These see identity as always in process, 'discursively produced ... within contexts of multi-layered structural inequalities' (Archer, 2008, p. 269). Thus identity is not a voluntary project of self-making. Rather, it is always set within 
a social, cultural and economic context, which sets limits on the kinds of identities that are available to particular selves: people position themselves within, and are positioned by, discourses. Identity work is thus inflected by inequalities of gender, class, 'race'/ethnicity, sexuality, disability and so on. Our focus in this paper is on how young people's identity work through celebrity discourses is informed by gender and class relations within neoliberalism.

\section{Methodology}

This paper draws on data from three separate research projects which share a concern with young people's career aspirations (see Table 1).

[Table 1: about here]

'Young women and the Performing Arts: Creative Education, New Labour and the remaking of the young female self' (henceforth abbreviated to 'Arts') was the Kim Allen's (2008) doctoral study. This research explored the educational experiences and career aspirations of young women aged 16-19 in Performing Arts education and training. Conducted in 2006-7, it involved interviews and focus groups with workingand lower-middle-class students from a range of ethnic backgrounds who attended two state-maintained institutions in South East England. Participants were interviewed about their educational choices, career aspirations and hopes for the future. The topic of celebrity entered participants' discussions on what kinds of careers they thought were desirable and the possible rewards of work in the performing arts.

'The impact of the depiction of work in TV drama on young people's career aspirations and choices' (henceforth abbreviated to 'Drama') was a study carried out jointly by Heather Mendick and Katya Williams (2008). This research examined how representations of work and workers in television drama influence young people's 
career aspirations and looked at intersections with class, gender and 'race'/ethnicity. In 2007-8, eighteen focus groups and thirty-one individual interviews were conducted with students aged 14-16 in three English schools. As participants responded to a range of questions about their relationship to television, their understanding of work and their future aspirations, they often discussed their views of celebrities and fame.

'Mathematical Images and Identities' (henceforth abbreviated to 'Maths') was led by Heather Mendick, and carried out jointly Debbie Epstein and Marie-Pierre Moreau (2008). The research explored the influence of representations of mathematics and mathematicians in popular culture on learners' relationships with the subject. Data were collected in 2006-7 through questionnaires, focus groups and individual interviews with school students (aged 15-16) and university students. In this paper, we draw on two sections of the forty-nine individual interviews, where participants were asked: to imagine a world where mathematicians appear on television regularly and to rank pictures of people and mathematics in terms of how much they thought they would like the people.

In each of these studies we used a similar analytic approach. Interviews and focus groups were audio-recorded and transcribed. Data were then coded for a range of themes derived both directly from the research focus and from those invoked by the research participants. Once coded the collected extracts were analysed discursively (Billig, 1992; Potter \& Wetherell, 1987). Pseudonyms, mostly chosen by participants, and some drawn from popular culture, are used throughout; since some are cross- or neutral-gender, we give this information. Social class was assigned by researchers and analysed using a 'culturalist' framework (Bourdieu, 1984). Within this, class position is understood not just through a subject's location within economic structures but also 
by their relationship to other resources or 'capitals', notably cultural capital (forms of knowledge, education, skills) and social capital (networks of support and influence).

We began to make connections between these projects through open dialogue about our work. As a result, we reviewed all the raw data from these studies to locate instances of young people's talk about celebrity culture (such as the process of becoming famous) and particular celebrities. Drawing on insights from the literature review, we asked: How did people mobilise discourses of work, talent and achievement in their constructions of celebrity? How did they assign value within these? And how did these relate to both wider discourses of social class and gender and to the social class and gender of the participants?

Drawing together data from multiple studies raises several issues. The participants come from different age ranges and areas of study which inevitably informs their relationships to celebrity. In particular, the Arts participants form a distinctive group, being exclusively female, working- or lower-middle-class and sharing a vocational location in performing arts. Discourses of celebrity were more acute within their accounts because these were strongly associated with their current studies and future employment (see Allen, 2011). We have also, necessarily had to select data from across a wide range of material and participants (see Table 2 for a summary of those participants mentioned in the paper). Celebrity was not the primary focus of any of the studies and it entered into discussions in different ways across them. There were some participants who never mentioned it. We have tried to indicate, in the sections that follow, when and how the data we have selected are more widely representative. However, all selectivity has limitations and overall we would argue that drawing across such a range of data illuminates the breadth of celebrity influence and gives robustness to emerging patterns. 
[Table 2: about here]

\section{Class distinctions: talent, labour and proper celebrity}

The majority of the young people interviewed who spoke about celebrity enacted dominant distinctions between proper and improper celebrity. These views were most vociferously expressed in the talk of middle- and lower-middle-class participants and so we focus on them in this section. We discuss the alternative responses given by working-class participants later in the paper. These distinctions between proper and improper celebrity relate to evaluations of the process through which celebrity is achieved and the form that it takes. Namely, proper celebrity is achieved through 'hard work' and the application of talent and takes the form of peer respect. Improper celebrity requires neither and takes pathological forms. The distinctions are clear in this participant's differentiation between being 'known for something I'm good at' and 'weird' fame, in and of itself that is represented by Reality TV shows such as The X-Factor ${ }^{3}$ :

Famous: I'd wanna be like known in ... the dance industry, I'd like [to] be known for something I'm good at. But I wouldn't wanna be like followed around by people ... it would be weird. It's not like normal. [female, lower-middle-class, Drama]

Similarly, Nancy makes these distinctions in relation to the mechanics of fame:

Nancy: The $X$-factor just churns people out ... there is this whole thing where everyone can be a celebrity but I think talent is important ... Real, proper actors who are actually respected ... not just because they're a name or an image but because they are valued for what they do.... People who are talented and who work hard and who sincerely want it. I'd rather have that. [female, lower-middle-class, Arts]

For Nancy, the Reality TV process does not produce 'real, proper' fame or reward 'talented' people 'who work hard', but embodies an undesirable fame based on a celebrity's 'name' and 'image' rather than their labour. Proper fame belongs to those who can be constructed as 'sincerely want[ing] it' and so as authentic. The use of 'churns ... out' in relation to the production of Reality TV fame, with its connotations 
of mechanised, mass production, reflects the low status attached to it within wider debates. Participants in all three studies constructed Reality TV show Big Brother as the epitome of improper celebrity:

Sandra Slater: I detest Big Brother ... there's something about Reality TV ... I see it as people getting paid to be famous. Whereas, I think you get famous because you have talent. ... If you're good at acting, if you're good at music, if you're a good comedian ...You shouldn't get famous just because your application was pulled out on the role for the Reality TV. [female, middle-class, Drama]

Here Sandra detaches talent and labour from Reality TV celebrity. It is understood to involve 'just' luck and to represent desires for fame, in and of itself.

These distinctions are powerfully linked to the project of neoliberal enterprising selfhood in which these young people were engaged. Drawing on the moral discourses (discussed earlier) which position particular celebrities as subjects without value or as abject others, these young people were constructing a particular image of themselves as ideal subjects who create their own success through hard work and self-responsibility. For example, Emma (female, lower-middle-class, Arts) distinguishes between 'proper success' that 'I've built myself on my talent and my hard work' and X-Factor fame, which would make her 'feel empty'.

The assertion of the importance of talent, work and 'real' fame was most elaborated by participants, like those quoted above, who were middle- or lowermiddle-class and had aspirations to work in areas related to celebrity (and therefore, a large proportion of these were from the Arts study). Their uses of celebrity took on significance in relation to an imagined future self. However, these distinctions also featured in the talk of young people who did not want fame. This was notable in the Maths research when participants were asked to discuss a world where mathematicians appear on television regularly. They too commonly invoked distinctions between proper and improper celebrities. For example, Abe (male, middle-class) compared the current celebrity culture populated by those 'who have 
got to be famous for not doing much', again typified by Big Brother housemates, with the 'clever people' who would be famous in this alternative world. While Abe does not explicitly mention 'chav celebrities', his views make sense in the context of discourses that position such celebrities as stupid. Often these distinctions were linked to oppositions between good and bad television. For example, Jane (female, middleclass) distinguished between 'bad TV that can waste quite a lot of time' and 'beneficial programs' that are educational. Such assessments of quality, and hence value, are always underlined by classed (and gendered) hierarchies (Holmes, 2004). The feeling that too many 'untalented' people have reaped benefits which should rightly go to the talented and thus 'more deserving' produced anger and resentment for many participants. This was focused most keenly on working-class celebrities. Such responses illustrate the ways that young people regulate themselves and others in drawing on discourses of improper celebrity. These middle-class participants were taking up dominant discourses around the negative effects of celebrity on young people. In this way, they distanced themselves from 'improper' celebrities and celebrity aspirations, and the pathologised status attached to them, and established themselves as ideal neoliberal subjects concerned with investing in the self. This positioning of the self as a 'sophisticated', distanced critic of improper celebrity mirrors the strategies of class distinction taken up by the middle-class women in Skeggs and Wood's (2008) research. In their study, middle-class responses to Reality TV drew upon 'a broader cultural debate about celebrity culture and in particular with a perceived lack of labour involved in "making it" ... [in which] effort and labour are directly connected to the rewards of paid work reliant on legitimate skills and education' (p. 566). In distinguishing between proper and improper pathways to fame, our participants, like the middle-class women in Skeggs and Wood's study, took up 
positions of class-based superiority. However, as we show in the last section of this article, middle-class strategies of distancing are unstable and can break down to reveal desires for celebrity. Furthermore, the rejection of the working-class or 'chav celebrity' is not always enacted. Before that, we examine the take-up of dominant discourses of gender and neoliberal subjectivity in young people's celebrity consumption.

\section{Gender distinctions: feminised spaces, bodies and improper celebrity}

Participants in all three studies, reflecting the place of female celebrities within dominant discourses improper fame outlined earlier, more often conflated female than male celebrities with improper and illegitimate celebrity. This was evident in discussions of WAGs, who incited strong opinions from our participants. For example, Carly (female, lower-middle-class, Arts) labelled Coleen McLoughlan and Victoria Beckham (wives of England footballers) and other 'girls [who] get a rich celebrity husband and [are known] for their make-up and clothes' as 'tacky" and 'lazy'. She also aligns them with Big Brother contestants and glamour models. By distancing herself from this type of 'celebrity' Carly - like the other participants cited earlier in the paper - is also constructing herself as an ideal female neoliberal subject who achieves success on the basis of her own work and effort, rather than her body or celebrity partner.

The gendering of improper celebrity is related to women's location in particular media formats, such as Reality TV and soap operas. As Holmes and Jermyn (2004) and Geraghty (1990) discuss, these are read as feminised spaces (through concerns with the intimate, domestic and private) and thus attributed with low cultural value. These associations between 'low' cultural forms, femininity and improper celebrity are evident in Vicky's (female, lower-middle-class, Arts) rejection of the 
idea of acting in British teen soap opera Hollyoaks: 'It would ruin my career because it's tacky acting, it's not even proper acting'.

However, although the gendering of improper celebrity was related to genre, it was more strongly articulated through discussions of women's bodies. This draws on a broader cultural opposition between mind and body and the long-standing association of women with the second, devalued term of this opposition (Lloyd, 1993). Women are culturally constructed as closer to their bodies than men and so have to do more work if they want to be seen as subjects of value and as intelligent (de Beauvoir, 1988). The role of the body in the gendering of improper celebrity is clear in Vicky's emphasis, in the extract below, on the visceral and the artificial: botox, fake boobs, hair straightening, make-up:

\footnotetext{
Vicky: There's too many TV shows that just want pretty, young, thin people who can't act for a penny ... full of botox, fake boobs ... who spend all their time straightening their hair and putting loads of make-up on. It's such a waste. It's so unreal ... You can be pretty with no personality and be a celebrity and I don't think that's right and I wouldn't want to do that. It's like the glamour thing, if you want to pose nude you can probably get there. It's an easier way to get to the top but I don't think it's the right way. [female, lower-middle-class, Arts]
}

Vicky clearly distances herself from 'easier' celebrity gained through using the hyperfeminine and (hetero)sexy body. This is already constituted as not requiring labour or talent and thus not 'the right way'. The distinctions mobilised here are significantly classed. They contain moral judgements through which a particularly 'excessive' hyper-feminine form of white working-class femininity is rejected (Archer et al, 2010; Skeggs, 1997). Such a form of femininity has historically been located as a failure of idealised neoliberal femininity within popular cultural texts such as 'makeover' television shows (see Ringrose \& Walkerdine, 2008). Furthermore, the labour that goes into the production and performance of this type of femininity (such as hair straightening and care for the female body) is rendered invisible and value-less. 
This opposition between mind and body, and its role in attributing value, was clearest in the Maths participants' responses to pictures of people and mathematics which included two women (see Mendick et al, 2008, for a more detailed discussion). One unknown woman was dressed in a lab-coat, had her hair tied back and an austere look on her face and featured on the cover of Time magazine. The other was a young, informally dressed and posed, American teen television actress, Danica McKellar, depicted surrounded by mathematical symbols. Participants found it easier to ascribe intellectual ability to the former picture. Thus, it was the woman who had concealed her hair and body who participants generally associated with intelligence and mathematical skill. In their judgements of MacKellar, participants picked up on aspects of her self-presentation. Leslie (male, unknown class) said of her: 'you don't really imagine mathematicians to be like, I don't know, casually dressed'. Candi (female, lower-middle-class) both aligning herself and distancing herself from the dominant discourse said, 'as much as I kind of hate to admit it myself, she just doesn't seem, doesn't seem like the type I'd imagine would be good at maths'. Here she implicitly draws attention to MacKellar's physical appearance.

As in the comments of Vicky earlier there was a conflation of the female body and particular feminised spaces. Thus, although MacKellar's celebrity status was less apparent to some of these participants than other better known celebrities discussed in this paper, similarly gendered processes of distinction-making were present. It appears to be both MacKellar's attractiveness and her (assumed) association with the entertainment industry that precludes her from being read as mathematical. Typically, Elizabeth (female, middle-class) said she appears unintelligent because she 'looks more like a popstar' and Pisces (male, middle-class) said, 'maybe I'm being stereotypical, but I don't consider actors as that clever'. Through this we again can see 
the playing out of oppositions between mind and body and the devaluing of feminised spaces. But what we can also identify are the risks associated with performing an idealised neoliberal femininity with its requirement to be beautiful and intelligent, attractive but not excessive (in terms of hyper-femininity or sexuality) (McRobbie, 2008).

In this and the previous section we have illustrated how young people re/produce neoliberal classed and gendered hierarchies of proper and improper celebrity within their identity work. However, this was not always the case. There was ambivalence in many of the young people's discussions of celebrity, and in some cases, participants contested dominant distinctions which position some celebrities (and desires for celebrity) as unworthy. In the next section we argue that this relates to their social positioning. First we look at social class and then at gender.

\section{Contesting dominant discourses: identifying with improper celebrity}

Contemporary celebrity culture is awash with neoliberal-aligned narratives of triumph over adversity and 'making it against the odds' (Littler, 2004). As such, celebrity culture offers important sites of fantasy and investment for young people, representing the possibility of visibility, symbolic capital and self-betterment. This may particularly be the case for those who, through their gender, class or ethnicity, face disadvantage in education and the labour market (Walkerdine, 1997). Thus, even for the female lower-middle-class participants, fame was not simply an inappropriate ambition. It also symbolised the ultimate validation of their achievements. While, as we showed above, these participants did reproduce wider cultural and political denouncements of improper celebrity through taking up the position of the distanced and sophisticated critic, fame was difficult to reject completely: 
Famous: Hopefully you'll see me dancing on the stage in a few years. ... I'll be in the West End with my name in lights. But it's really competitive. [female, lower-middleclass, Drama]

Carly: I have such expectations on me. Everyone in my home town is like, "wow, she's gonna be so famous" ... I do want to impress people ... I do wanna be famous and I want people to see. I don't want them to say, "ha, she failed!" [female, lower-middle-class, Arts]

These quotes represent moments of slippage within the middle-class presentation of the self as the ideal neoliberal subject. For Carly and Famous, despite their rejections of improper celebrity (discussed earlier), desires for fame seep through. For Famous, her desires for celebrity are revealed in her choice of pseudonym and in the vivid image of seeing her 'name in lights'. For Carly, they are articulated in how she imagines others' expectations of her and the way in which she equates not achieving fame with personal failure. These quotations suggest that it is a struggle to align the self with 'legitimate' success through repudiating improper celebrity when fame is both a site of recognition and achievement and constructed as inauthentic and shallow. They also illustrate that young people's negotiations of celebrity (like our own) combine compliance and resistance to dominant discourses. In this section we look at some other alternative readings of celebrity.

All of the working-class young women in the Arts study were more explicit than their lower-middle-class counterparts in their desire for fame. Among these participants, the rewards of fame (recognition, autonomy and economic security) were highly desirable and distinctions between legitimate and illegitimate success less relevant. They positioned celebrity via Reality TV as an 'opportunity structure' (Skeggs \& Wood, 2008, p. 567) to provide for themselves and others. Furthermore, there was evidence of an inversion of the celebrity hierarchies of value. Celebrities who had gained their status through making the most of the opportunities available within the celebrity industry - and the labour involved in achieving this - were 
valued. Anusha (female, working-class, Arts) praised Reality TV contestant Jade

Goody: 'She's clever and she's worked hard for what she's got and she ain't changed for no one either, so I've got a lot of respect for her'. Anusha rejected dominant classifications of improper celebrity premised on a lack of talent, skill or legitimate labour. For her, Jade Goody deserves her fame, talented or not, because of her 'graft' and working-class 'authenticity'.

A group of lower-middle-class young women in the Drama project expressed admiration for WAGs and their glamorous lifestyles.

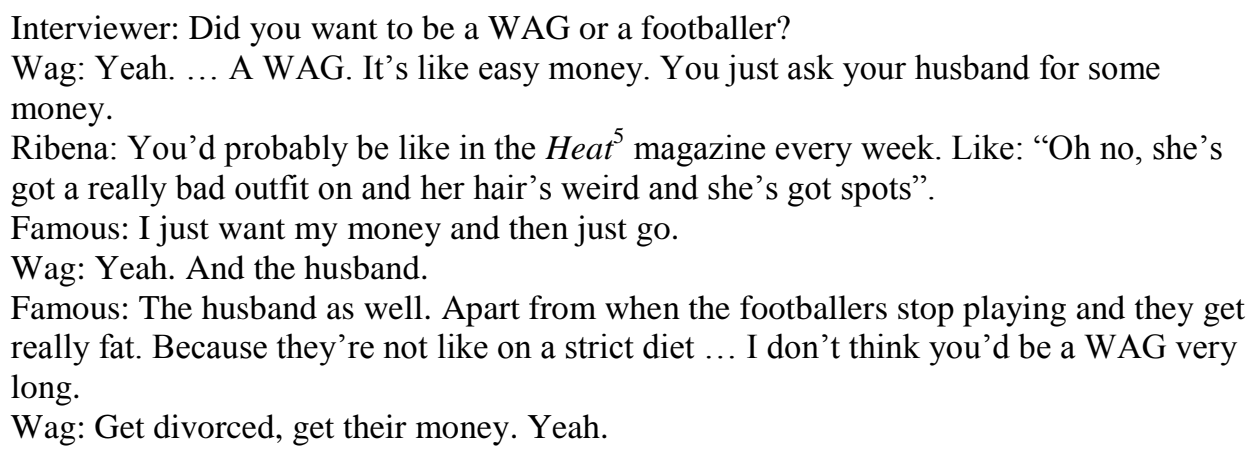

Wag and Famous later went on to discuss how they chose to celebrate their sixteenth birthday with a Footballers' Wives ${ }^{6}$ themed party, complete with red carpet. Again, these young women were rejecting dominant hierarchies of fame by attributing value to the WAG lifestyle and seeing it as offering an 'opportunity structure'. They also emphasised the labour involved, for example, in managing their husband's diet and negotiating the inevitable media intrusion.

In a final example, in the Maths research, the female social sciences and humanities university students expressed different views than the dominant ones discussed earlier about the picture of Danica MacKellar. In contrast with the dismissals of MacKellar evident in the talk of the GCSE and mathematics university students, all but one of them were positive about her. Grace and Donna (both female, middle-class) described her as 'confident' and Mansa (female, middle-class) as a 
'very intelligent' and 'nice young lady'. Mansa, Sam, Louise, Ellie and Maria all liked the way she interrupts the stereotype of mathematicians as male and suggested that she shows that you can be clever and attractive, as Ellie (female, middle-class) put it: 'it's saying you can be attractive and intelligent and study maths and it's not a bad thing'. Although Louise (female, middle-class) seemed surprised that MacKellar takes care of her appearance and looks fashionable as well as being into mathematics, she too is able to attribute her with positive value. These comments challenge oppositions between mind and body that constrain female celebrities in particular and women in general. These women have mixed class, ethnic and national backgrounds, some were in elite institutions and some at lower status universities. All had taken courses on gender as part of their degrees and most had a commitment to feminism. We would suggest that these resources allowed them to read these images positively.

We acknowledge that it is problematic to read these responses simply as 'resistance' to wider dominant discourses which dismiss some forms of celebrity as improper (just as it is problematic to read the participants' talk in previous sections simply as compliance to these discourses). Participants' rejection (and take-up) of dominant discourses is always doubled-edged. For example, Wag and Famous, in rejecting discourses that denigrate the WAG as an inappropriate ambition and celebrating the WAG's fame and use of celebrity as a way of gaining economic status, simultaneously desire female dependency within heterosexual marriage. There are parallels with Willis' (1977) working-class 'lads', whose resistance to schooling confined them to working-class jobs, and with Walkerdine's (1998) nursery schoolgirls, whose resistance to role-playing an inferior position to the boys led them to take pleasure in domesticity, thereby reproducing normative gendered identities. Thus, the girls' investment in dominant formations of hyper-heterosexual femininities 
within their uses of celebrity can be understood as part of a general pattern where 'doing girl' within neoliberalism plays into other oppressive power relations (Archer, et al., 2010). Similarly, Anusha's appraisal of Jade Goody's working class 'authenticity' and refusal to change as valuable to her celebrity status is potentially problematic. Anusha's attachment to authenticity can function to keep her in her place, fixing her as working-class and happy to be there (Walkerdine \& Lucey, 1989). Furthermore, investments in celebrity culture as an opportunity structure are informed by and can reproduce wider cultural and political discourses of meritocracy (such as that espoused by the New Labour government when this research took place and continued under the new coalition government in the UK) which problematically individualise 'success' and 'failure' and obscure social and economic inequalities (see Allen, 2011).

As Butler (1997) argues we are all located within power relations that are simultaneously productive and oppressive; resistance does not permit escape from these. However, these young people's talk needs to be recognised and carefully considered. We would suggest that the above data show evidence that people can and do mobilise counter-discourses in their relationships to celebrity. Notably, rather than take-up discourses that construct talentless celebrity as improper, some young people ascribe value to such subjects.

\section{Conclusions}

In this article, we have drawn on findings from three independent studies to explore how celebrity functions in the everyday lives of young people in England. We end by suggesting some implications of our analysis.

First, young people in these studies were aware of wider cultural and political discourses which construct hierarchies of legitimate fame (and associated hierarchies 
of legitimate selves). However, they do not take these up in a straightforward manner but in an ongoing process of negotiation which is informed by other aspects of their identity work. In this sense, young people's relationship to celebrity must be understood as a social practice, where social class and gender operate as significant but not predictable organising structures in young people's narratives.

Second, although the majority of the participants discussed here are female, celebrity also played out in the identity work of, at least some, young men. Young men's uses of celebrity should be a focus for future research, as should issues of 'race'/ethnicity in young people's uses of celebrity. Similarly, this article draws on research with young people in England. It would therefore be useful for scholarship to explore young people's relationships with the discourses of celebrity in other national contexts, especially in non-western countries.

More generally, this article suggests that we need to take pleasure and identification with celebrity seriously as part of people's identity work and attend to its regulatory and disciplinary consequences. We should ask: what happens when young people position themselves through neoliberal discourses of celebrity which classify them as subjects with or without value? What classed and gendered judgements are mobilised? For people studying performing arts it affects their career choices directly by rendering illegitimate some ways of being. These young people had to avoid or defend desires for celebrity as they contemplated a career in the entertainment industry. Indeed the distinctions contained within celebrity discourses, and which these young people were negotiating, parallel those marking out legitimate and desirable educational pathways and careers. As Ball, Maguire and Macrae (2000) have shown by drawing on the work of Bourdieu (1984), distinctions between educational and career pathways also reproduce class (and gender) inequalities. Such 
distinctions include those between vocational and academic qualification routes and between professional careers and careers in manual trades or hairdressing. The identity work young people do with celebrity contributes to these more general processes through which some choices are attributed with more value than others. Further, celebrity is imbricated in wider regimes of power, functioning symbolically to classify individuals as worthy and unworthy via the circulation of discourses of hard work, talent and ambition. These discourses bleed into other relationships in educational settings, such as those between peers and between teachers and students, creating value hierarchies (Kitching, 2009).

In order to understand contemporary celebrity we, along with Turner (2010) would argue that we need a stronger focus on audience consumption through empirical studies:

I think we can develop more, and other kinds of, material for this task by approaching celebrity through a more varied range of, methodological strategies - some of them drawn from more empirical modes of enquiry. (Turner, 2010, p. 19)

While, textual analysis offers a more critical perspective on celebrity culture than political and public discourses, it gives the impression of an inevitability to the production of neoliberal selfhood through celebrity representations. However, empirical analysis can reveal discontinuities and ambivalences within people's uses of celebrity. We have shown that there is nothing inevitable or fixed in the ways that young people take-up the classed and gendered discourses of the self. For example, we showed that some young people challenged the idea that being a Reality TV star or a WAG is a value-less position that requires no work and some female university students challenged the idea that attractive women celebrities must lack intellect. These alternative and contested readings hold the possibility of relating to celebrity discourses in other ways and therefore must be attended to. Not least because we have also shown that, for young women and working-class people, the regulation of 
neoliberal selfhood is paradoxically punitive, thus making it crucial to identify the complexity of its workings. We hope to have contributed to that project.

Acknowledgements: We are grateful to the participants in the research drawn on here and to the funders of this work: Arts was funded by the Arts and Humanities Research Council, Drama by the British Academy and Maths by the Economic and Social Research Council (RES-000-23-1454) and the UK Resource Centre for Women in Science Engineering and Technology. In addition to the researchers mentioned in the article, we acknowledge the contributions of Teresa Cabajo Garcia, Nathan Fretwell and Sumi Hollingworth. We would also like to thank Jocey Quinn, Marie-Pierre Moreau, Bev Skeggs, Imogen Tyler, Rosalyn George, Sumi Hollingworth and Charmian Kenner for reading and commenting on earlier drafts of this article. We are also grateful to the reviewers' comments for helping us improve this article. 
Table 1. Summary of Projects.

\begin{tabular}{|c|c|c|c|}
\hline & Arts & Drama & Maths \\
\hline $\begin{array}{l}\text { Number of } \\
\text { participants }\end{array}$ & 20 & $\begin{array}{l}31 \text { interviewees (98 } \\
\text { focus group } \\
\text { participants) }\end{array}$ & 49 interviewees \\
\hline Age & $16-19$ & 14-16 & 15-16 and adult \\
\hline Gender & All female & 19 female, 12 male & 28 female, 21 male \\
\hline Social class & $\begin{array}{l}9 \text { working-class, } 11 \\
\text { lower-middle-class }\end{array}$ & $\begin{array}{l}10 \text { working-class, } 8 \\
\text { lower-middle, } 11 \\
\text { middle-class, } 2 \\
\text { unknown }\end{array}$ & $\begin{array}{l}10 \text { working-class, } 10 \\
\text { lower-middle, } 20 \\
\text { middle-class, } 9 \\
\text { unknown }\end{array}$ \\
\hline Ethnicity & $\begin{array}{l}7 \text { White British, } 6 \\
\text { Black Caribbean, } 4 \\
\text { mixed heritage, } 1 \\
\text { Black African, } 2 \\
\text { White other }\end{array}$ & $\begin{array}{l}9 \text { White British, } 12 \\
\text { Asian, } 2 \text { Black } \\
\text { Caribbean, } 2 \text { mixed } \\
\text { heritage, } 1 \text { Black } \\
\text { African, } 1 \text { White } \\
\text { other, } 1 \text { Iraqi, } 1 \\
\text { Chinese, } 1 \text { Lebanese }\end{array}$ & $\begin{array}{l}31 \text { White British, } 4 \\
\text { Black African, } 4 \\
\text { Black Caribbean, } 4 \\
\text { White Other, } 3 \\
\text { Asian, } 2 \text { mixed } \\
\text { heritage, } 1 \text { unknown }\end{array}$ \\
\hline
\end{tabular}


Table 2. Summary of Participants Discussed in the Paper.

\begin{tabular}{|c|c|c|c|c|c|}
\hline Pseudonym & Social class & Gender & $\underline{\text { Age }}$ & Ethnicity & Study \\
\hline Abe & middle & male & $15-16$ years & White British & Maths \\
\hline Anusha & working & female & 19 years & Black Caribbean & Arts \\
\hline Candi & lower-middle & female & $15-16$ years & White British & Maths \\
\hline Carly & lower-middle & female & 18 years & White British & Arts \\
\hline Donna & middle & female & 30-39 years & Black Caribbean & Maths \\
\hline Elizabeth & middle & female & 19-25 years & White British & Maths \\
\hline Ellie & middle & female & 19-25 years & White British & Maths \\
\hline Emma & lower-middle & female & 16 years & White British & Arts \\
\hline Famous & lower-middle & female & 15-16 years & White British & Drama \\
\hline Grace & middle & female & 30-39 years & Black Caribbean & Maths \\
\hline Jane & middle & female & $15-16$ years & White British & Maths \\
\hline Leslie & unknown & male & 15-16 years & Asian & Maths \\
\hline Louise & middle & female & 19-25 years & White British & Maths \\
\hline Mansa & middle & female & 30-39 years & Black African & Maths \\
\hline Maria & middle & female & 40-49 years & Black Caribbean & Maths \\
\hline Nancy & lower-middle & female & 17 years & White British & Arts \\
\hline Pisces & middle & female & $15-16$ years & White/Black African & Maths \\
\hline Ribena & lower-middle & female & 15-16 years & White British & Drama \\
\hline
\end{tabular}




\begin{tabular}{|l|l|l|l|l|l|} 
Sam & middle & female & $19-25$ years & Asian (Indian) & Maths \\
\hline Sandra Slater & middle & female & $15-16$ years & White British/American & Drama \\
\hline Vicky & lower-middle & female & 18 years & White British & Arts \\
\hline Wag & lower-middle & female & $15-16$ years & White British & Drama \\
\hline
\end{tabular}


1. Aspiration is a fraught concept which itself produces exclusion. For example, in UK Government discourses of educational achievement and Widening Participation in Higher Education there are assumptions that particular young people (and parents) - mainly working class - 'lack' aspirations and need them raising. These are underlined by problematic assumptions of deficit and failure. Here we use the term 'aspirations' to refer to young people's desires for and perspectives on their future relationships to education and work. We concur with Burke (2006, p. 720) that processes of aspiration-making are 'tied in with complex sets of shifting identifications...[and] are discursively re/fashioned through complex negotiations made within social contexts and relations'.

2 Both Katona and Goody are female working class celebrities. Kerry Katona was briefly in the British female pop band Atomic Kitten before featuring in a series of Reality TV programmes. Jade Goody became famous when she participated in the third series of UK Big Brother in 2002. She was famously vilified in the press but revived her career through a range of other Reality TV shows. She died of cancer in 2009.

3. The X-Factor (ITV) is British reality TV show which began in 2004, replacing similar shows Pop Idol (ITV) and Pop Stars (ITV). Based on the format of a signing contest, contestants are selected from national auditions and compete on live shows to win a record contract. The $X$-Factor has also been launched successfully in several other countries.

4. 'Tacky' is a colloquial word used to describe persons or things that are perceived to be lacking style or good taste.

5. Heat magazine is a British celebrity gossip magazine, launched in 1999. It is a leader in the celebrity weekly magazine market. For a critical analysis of Heat and its readers see Feasey (2008) and Holmes (2005).

6. Footballers' Wives was a popular British television drama, based on the lives of footballers and their spouses. It aired on the UK television channel ITV from 2002 to 2006.

\section{References}

Allen, K. (2008). Young women and the Performing Arts: Creative Education, New Labour and the remaking of the young female self. $\mathrm{PhD}$, Goldsmiths University of London, London.

Allen, K. (2011). Girls imagining careers in the limelight: social class, gender and fantasies of "success". In S. Holmes \& D. Negra (Eds.), In the Limelight and Under the Microscope: Forms and Functions of Female Celebrity (pp. 149173). London: Continuum.

Allen, K., \& Osgood, J. (2009). Young women negotiating maternal subjectivities: the significance of social class. Studies in the Maternal, 1(2), online.

Ang, I. (1996). Feminist Desire and Female Pleasure. In J. Storey (Ed.), Cultural Studies and the Study of the Popular: theories and methods (pp. 513-522). Edinburgh: Edinburgh University Press.

Archer, L. (2008). The neoliberal subject? Young/er academics' constructions of professional identity. Journal of Education Policy, 23(3), 265-285.

Archer, L., Hollingworth, S., \& Mendick, H. (2010). Urban youth and schooling. Maidenhead: Open University Press.

Ball, S. J., Maguire, M., \& Macrae, S. (2000). Choice, pathways and transitions post16. London: RoutledgeFalmer.

BBC. (2008). Celebrity culture 'harms pupils' Retrieved 17 October 2007, from http://news.bbc.co.uk/1/hi/education/7296306.stm

Billig, M. (1992). Talking of the royal family. London: Routledge.

Bourdieu, P. (1984). Distinction. London: Routledge. 
Buckingham, D., \& Bragg, S. (2004). Young people, sex and the media: the facts of life? Basingstoke, Hampshire: Palgrave Macmillan.

Burke, P. J. (2006). Men accessing education: gendered aspirations. British Educational Research Journal, 32(5), 719-733.

Butler, J. (1997). The psychic life of power. Stanford: Stanford University Press.

Chapman, J. (2008). 'Barbie doll' girls only want to be WAGs or win the X Factor, complains Culture Minister. Retrieved 17 October 2008, from http://www.dailymail.co.uk/news/article-1077444/Barbie-doll-girls-wantWAGs-win-X-Factor-complains-Culture-Minister.html

Couldry, N. (2000). The Place of Media Power: Pilgrims and Witnesses of the Media Age. London: Routledge.

DCSF/DCMS. (2009). The Impact of the Commercial World on Children's Wellbeing: Report of an Independent Assessment. London: DCSF.

de Beauvoir, S. (1988). The second sex. London: Pan Books.

du Gay, P. (1996). Consumption and identity at work. London: Sage.

Dyer, R. (2003). Heavenly Bodies: Film Stars and Society. London: Routledge.

Foucault, M. (1972). The archaeology of knowledge. London: Routledge.

Geraghty, C. (1990). Women and Soap Opera. Oxford: Polity Press.

Holmes, S. (2004). All you've got to worry about is the task, having a cup of tea, and what you're going to eat for dinner": Approaching Celebrity in Big Brother. In S. Holmes \& D. Jermyn (Eds.), Understanding Reality Television. London: Routledge.

Holmes, S., \& Jermyn, D. (2004). Introduction. In S. Holmes \& D. Jermyn (Eds.), Understanding Reality Television (pp. 1-32). London: Routledge.

Learning and Skills Council. (2007, 24 October). WAG wannabes told to get grades, Press Release.

Littler, J. (2004). Celebrity and 'Meritocracy'. Soundings, 26, 118-130.

Lloyd, G. (1993). The man of reason: 'male' and 'female' in Western philosophy. London: Routledge.

Marsh, J., Brooks, G., Hughes, J., Ritchie, L., Roberts, S., \& Wright, K. (2005). Digital Beginnings: Young Children's Use of Popular Culture, Media and New Technologies. Sheffield: University of Sheffield.

McRobbie, A. (2004). Post-Feminism and Popular Culture. Feminist Media Studies, $4(3), 255-264$.

McRobbie, A. (2008). The Aftermath of Feminism: Gender, Culture and Social Change. London: Sage.

Mendick, H., Epstein, D., \& Moreau, M.-P. (2008). End of Award Report: Mathematical Images and Identities: Education, Entertainment, Social Justice. Swindon: Economic and Social Research Council.

Mendick, H., Moreau, M.-P., \& Hollingworth, S. (2008). Mathematical Images and Gender Identities: a report on the gendering of representations of mathematics and mathematicians in popular culture and their influences on learners. Bradford: UK Resource Centre for Women in Science Engineering and Technology.

Mendick, H., \& Williams, K. (2008). The impact of representations of work and workers in television drama on young people's career aspirations and choices: end of award report. London: IPSE.

Nayak, A., \& Kehily, M. J. (2008). Gender, Youth and Culture: Young Masculinities and Femininities. Basingstoke: Palgrave. 
Negra, D., \& Holmes, S. (2008). Introduction: GOING CHEAP? Female Celebrity in Reality, Tabloid and Scandal Genres. Genders Online(48).

Papadopoulos, L. (2010). Sexualisation of young people review. London: Home Office.

Potter, J., \& Wetherell, M. (1987). Discourse and social psychology: beyond attitudes and behaviour. London: Sage.

Read, B. (2011). Britney, Beyoncè and me - primary school girls' role models and constructions of the 'popular' girl. Gender and Education, 23(1), 1-13.

Ringrose, J., \& Walkerdine, V. (2008). The TV make-over as site of neo-liberal reinvention toward bourgeois femininity. Feminist Media Studies, 8(3), 227246.

Rose, N. (1999). Governing the soul (2nd ed.). London: Free Association Books.

Skeggs, B. (1997). Formations of Class and Gender. London: Sage.

Skeggs, B., \& Wood, H. (2008). The labour of transformation and circuits of value 'around' reality television. Continuum: Journal of Media \& Cultural Studies, 22(4), 559-572.

Skeggs, B., Wood, H., \& Thumim, N. (2007). Making Class through Moral Extension on Reality TV Retrieved 3rd Feb, 2009, from http://www8.umu.se/medfak/cgf/bev\%20warwick\%20with\%20edits\%20_2_.p $\underline{\mathrm{df}}$

Tasker, Y. (1998). Working girls: gender and sexuality in popular cinema. Abingdon: Routledge.

Turner, G. (2010). Approaching celebrity studies. Celebrity Studies, 1(1), 11 - 20.

Tyler, I., \& Bennett, B. (2010). Celebrity Chav: Fame, Femininity and Social Class. European Journal of Cultural Studies, 13(3), 375-393.

Walkerdine, V. (1997). Daddy's girl. Hampshire: Macmillan.

Walkerdine, V. (1998). Counting girls out (2nd ed.). London: Falmer.

Walkerdine, V., \& Lucey, H. (1989). Democracy in the kitchen: regulating mothers and socialising daughters. London: Virago.

Walkerdine, V., Lucey, H., \& Melody, J. (2001). Growing up girl: psychosocial explorations of gender and class. Basingstoke: Palgrave.

Willett, R. (2011, in press). An Ethnographic Study of Preteen Girls' Play with Popular Music on a School Playground in the UK. Journal of Children and Media, 5(4).

Willis, P. (1977). Learning to labour: how working class kids get working class jobs. London: Gower Publishing.

Woolcock, N. (2008). Forget education, pupils just want to be famous. Retrieved 3rd February, 2009, from http://www.timesonline.co.uk/tol/life_and_style/education/article3549319.ece 